\title{
KEMAMPUAN BERPIKIR KRITIS MATEMATIS DITINJAU DARI ADVERSITY QUOTIENT
}

\author{
${ }^{1}$ Nita Rahayu, ${ }^{2}$ Fitri Alyani \\ Universitas Muhammadiyah Prof.Dr.HAMKA, Jl. Tanah Merdeka No.20, RT.11/RW.2, Rambutan, \\ Kec. Ps. Rebo, Kota Jakarta Timur, Daerah Khusus Ibukota Jakarta 13830, +62(021) 7394451, Indonesia \\ e-mail: fitrialyani@uhamka.ac.id
}

\begin{abstract}
Abstrak
Kemampuan berpikir kritis merupakan salah satu kemampuan yang harus dimiliki peserta didik dalam menghadapi tantangan abad ke-21. Dalam memecahkan suatu permasalahan matematika, setiap peserta didik memiliki respon yang berbeda dalam menyikapi kesulitan tersebut yang dinamai dengan Adversity Quotient (AQ). Adversity Quotient terbagi menjadi tiga tipe, yaitu tipe climber, tipe camper, dan tipe quitter. Penelitian ini bertujuan untuk menganalisis kemampuan berpikir kritis matematis berdasarkan Adversity Quotient siswa kelas XI dalam menyelesaikan permasalahan materi barisan dan deret berdasarkan indikator berpikir kritis yang telah disusun. Subjek dalam penelitian ini adalah siswa kelas XI MIPA tahun ajaran 2019/2020 yang berjumlah 104 siswa. Instrumen pengumpulan data yang digunakan antara lain soal tes untuk melihat kemampuan berpikir kritis matematis siswa yang telah disesuaikan dengan indikator berpikir kritis dan non tes berupa angket Adversity Quotient (AQ). Instrumen tes dan non tes diukur menggunakan Model Rasch dibantu oleh software Winstep dan SPSS versi 24.0. Berdasarkan hasil pengolahan data, sebagian besar peserta didik berada pada tipe campers. AQ memberikan pengaruh positif terhadap pencapaian kemampuan berpikir kritis matematis siswa. AQ dan kemampuan berpikir kritis matematis memiliki korelasi/hubungan yang signifikan sehingga terdapat penjabaran mengenai tipe-tipe AQ.
\end{abstract}

Kata Kunci: Adversity Quotient, Kemampuan berpikir kritis matematis, Model Rasch, Barisan dan deret

\begin{abstract}
Critical Thinking Ability is one of the abilities students must have in facing the challenges of the 21 st century. In solving a mathematical problem, each student has a different response in dealing with these difficulties called Adversity Quotient (AQ). Adversity Quotient is divided into three types, namely climber type, camper type, and quitter type. This study aims to analyze the mathematical critical thinking ability based on the Adversity Quotient of class XI students in solving row and series material problems based on the critical thinking indicators that have been prepared. The subjects in this study were students of class XI MIPA in the 2019/2020 school year, totaling 104 students. Data collection instruments used include test questions to see students' mathematical critical thinking abilities that have been adapted to critical thinking and non-test indicators in the form of an Adversity Quotient (AQ) questionnaire. Test and non-test instruments were measured using the Rasch Model aided by the Winstep software and SPSS version 24.0. Based on the results of data processing, most students are in the camper type. AQ has a positive influence on the achievement of students' mathematical critical thinking abilities. AQ and mathematical critical thinking skills have a significant correlation/relationship, so there is a description of the types of AQ.
\end{abstract}

Keywords: Adversity Quotient, Mathematical critical thinking ability, Rasch model, Sequences and series

\section{PENDAHULUAN}

Pada abad ke-21, masyarakat yang kompleks membutuhkan orang-orang yang mampu menganalisis dan menanggapi masalah dalam dunia berbasis pengetahuan yang terus berkembang (Lutfianto \& Hartono, 2013). Sistem pendidikan di seluruh dunia mencari praktik terbaik untuk mempersiapkan anak-anak dan remaja di sekolah saat ini untuk menghadapi kehidupan dan bekerja dengan persyaratan yang semakin kompleks di abad ke-21 (Cretu, 
2017). Untuk menghadapi tantangan abad ke-21 setiap orang harus memilki 6 keterampilan yang mencakup: critical thinking, collaboration, communication, creativity, citizenship/ culture, and character education/connectivity (Anugerahwati, 2019; Indriani, 2017). Berpikir kritis muncul sebagai komponen untuk mempersiapkan generasi abad ke-21 untuk bertahan dengan perubahan zaman (Kusaeri \& Aditomo, 2019). Sejumlah penelitian (As'ari et al., 2017; Firdaus \& Kailani, 2015) menyimpulkan bahwa matematika memiliki peran potensial dalam mengembangkan keterampilan berpikir kritis.

Sementara itu, Permendikbud No. 23 tahun 2016 Dalam Standar Isi untuk Satuan Pendidikan Dasar dan Menengah menyebutkan bahwa salah satu tujuan dari matematika di sekolah adalah siswa mampu menunjukkan sikap logis, kritis, analitis, cermat dan teliti, bertanggung jawab, responsif, dan tidak mudah menyerah dalam memecahkan masalah (Kemendikbud, 2016). Mengembangkan kemampuan logis, kritis, analisis, cermat dan teliti, bertanggung jawab, responsif, dan tidak menyerah yang menjadi fokus dan perhatian guru matematika di kelas, karena hal itu berkaitan dengan keilmuan matematika. Senada dengan hal tersebut, beberapa peneliti (Ab Kadir, 2017; Tiruneh et al., 2017; Widyatiningtyas et al., 2015) menyatakan bahwa salah satu yang harus dikembangkan adalah kemampuan berpikir kritis.

Meskipun telah disebutkan bahwa berpikir kritis menjadi salah satu keterampilan yang harus dikembangkan, namun faktanya kemampuan berpikir kritis matematis siswa Indonesia masih rendah dan belum memuaskan. Berdasarkan hasil studi internasional mengenai prestasi matematika siswa Indonesia yang dilakukan oleh Trend in International Mathematics and Science Study (TIMSS) pada tahun 2015 menunjukkan bahwa Indonesia berada di peringkat ke-44 dari 49 negara dengan rata-rata 397 dari skor rata-rata Internasional sebesar 500 (Mullis, et. al., 2015). Hal ini mengalami penurunan peringkat dari hasil TIMSS tahun 2011 yang berada di peringkat ke-38 dari 42 negara. Sedangkan dari data Programme for International Srudent Assessment (PISA) yang digagas oleh Organization for Economic Co-operation and Development (OECD) tahun 2018 yang menempatkan Indonesia berada di peringkat ke-73 dari 79 negara dengan rata-rata 386 dari skor rata-rata OECD sebesar 489 (OECD, 2019). Hal ini menunjukkan bahwa skor rata-rata Indonesia masih di bawah rata-rata dan peringkat Indonesia dari tahun ke tahun tidak jauh berbeda dan masih di bawah negara-negara lain.

Ada beberapa faktor yang berkontribusi menyebabkan rendahnya hasil skor PISA dan TIMSS Indonesia. Salah satu faktor penyebab rendahnya hasil PISA dan TIMSS adalah bahwa siswa tidak terbiasa untuk memecahkan masalah matematika yang menuntut keterampilan berpikir kritis (Kusaeri \& Aditomo, 2019; Mahmuzah \& Ikhsan, 2014). Hal ini dikarenakan 
peserta didik masih mengalami kesulitan dalam menyelesaikan soal matematika yang menekankan pada keterampilan merumuskan dan menafsirkan suatu permasalahan untuk mendapatkan strategi pemecahan masalah matematika yang tepat. Sehingga dalam menyelesaikan suatu permasalahan matematika peserta didik mengalami kesulitan dalam menyelesaikannya. Selain itu, pembelajaran matematika kurang terhubung dengan konteks kehidupan yang dihadapi siswa dan kurang memfasilitasi siswa dalam mengekspresikan argumentasi dan proses berpikir mereka (Rahman et al., 2014).

Fokus pembelajaran matematika saat ini yang membutuhkan lebih pada pemahaman konseptual dan kemampuan untuk memberikan justifikasi daripada hanya menerapkan aturan matematika, menunjukkan bahwa matematika memiliki peran potensial untuk pengembangan berpikir, termasuk berpikir kritis (As'ari et al., 2017). Berpikir kritis (keterampilan berpikir kritis) telah menjadi salah satu alat yang digunakan dalam kehidupan kita sehari-hari untuk menyelesaikan beberapa masalah karena melibatkan penalaran logis, menafsirkan, menganalisis, dan mengevaluasi informasi untuk memungkinkan seseorang membuat keputusan yang andal dan valid (Widana, 2018).

Berdasarkan teori, indikator pemikiran kritis dikembangkan untuk menganalisis dan mengevaluasi argumen dan bukti, mengklarifikasi, membuat pertimbangan, membuat penjelasan, dan mengidentifikasi asumsi (Dhayanti \& Johar, 2018). Richard Paul dan Linda Elder mendefinisikan pemikiran kritis sebagai seni untuk meningkatkan keterampilan berpikir dalam menganalisis dan mengevaluasi pemecahan masalah tertentu (Widana, 2018). Sementara itu Facione (2011) berpendapat bahwa konsep pemikiran kritis yang paling mendasar adalah kemampuan interpretasi, analisis, evaluasi, inferensi, penjelasan dan pengaturan diri.

Dalam memecahkan suatu permasalahan matematika, setiap peserta didik memiliki respon yang berbeda-beda. Beberapa peserta didik menganggap bahwa permasalahan matematika tersebut sebagai tantangan yang harus dihadapi dan diselesaikan, sedangkan peserta didik lain menganggap bahwa permasalahan matematika yang dihadapinya merupakan sebuah masalah yang sulit sehingga mereka tidak mampu menghadapinya. Respon peserta didik dalam menyikapi suatu kesulitan yang disebut Adversity Quotient (AQ) yang diperkenalkan oleh Paul G. Stoltz.

Stoltz (1997) menyatakan bahwa AQ adalah kecerdasan seseorang dalam menghadapi dan mengatasi kesulitan secara teratur dan dapat menjadi indikator untuk melihat seberapa kuatkah sesorang dapat terus bertahan dalam suatu masalah yang dihadapinya. Fakta bahwa 
dalam proses penyelesaian masalah matematika, beberapa peserta didik ada yang mudah menyerah dalam mengerjakan soal matematika tersebut karena mereka mengalami kesulitan dalam mengerjakannya (Hidayat \& Prabawanto, 2018; Parvathy, 2014; Yanti \& Syazali, 2016). Adversity Quotient mempunyai tiga tipe tingkatan (Amin \& Khabibah, 2019; MZ et al., 2017) yaitu : (1) Climber adalah sekelompok orang yang siap menghadapi rintangan yang ada dan jika menemukan masalah yang sulit dipecahkan maka mereka akan berusaha semaksimal mungkin untuk menyelesaikannya, (2) Camper adalah sekelompok orang yang masih ada keinginan menghadapi rintangan tetapi mudah puas dengan apa yang telah dicapai dan tidak berusaha semaksimal mungkin, (3) Quitter adalah sekelompok orang yang menghindar dari masalah, mudah putus asa, mudah menyerah dan jika dihadapkan dengan kesulitan mereka akan mundur.

Berdasarkan penelitian yang dilakukan oleh Hidayat \& Sari (2019), AQ memberikan pengaruh positif terhadap pencapaian kemampuan berpikir kritis matematis siswa SMP dan terdapat perbedaan pencapaian kemampuan berpikir kritis siswa ditinjau berdasarkan tingkatan AQ. Penelitian yang lain oleh Amanah (2017), terdapat pengaruh positif AQ dan kemampuan berpikir kritis siswa SMP secara bersama-sama terhadap prestasi matematika. Jadi dapat disimpulkan bahwa AQ memberikan pengaruh positif terhadap kemampuan berpikir kritis matematis siswa.

Pada penelitian yang disebutkan di atas, sampel yang digunakan yaitu siswa SMP dan analisis data hanya menggunakan SPSS dengan melakukan uji normalitas, uji linearitas, uji regresi, uji korelasi, dan uji one-way ANOVA. Oleh karena itu, peneliti merasa tertarik untuk melakukan pengembangan penelitian dengan sampel siswa SMA dan analisis data angket menggunakan pendekatan Rasch Model dan kemampuan berpikir kritis dihitung menggunakan nilai logit model Rasch kemudian dianalisis menggunakan SPSS serta dijelaskan lebih detail indikator berpikir kritis berdasarkan tingkatan AQ (Climber, Camper, dan Quitter).

Berdasarkan uraian di atas, penelitian ini bertujuan untuk menganalisis kemampuan berpikir kritis matematis berdasarkan Adversity Quotient siswa kelas XI dalam menyelesaikan permasalahan materi barisan dan deret berdasarkan indikator berpikir kritis yang telah disusun.

\section{METODE PENELITIAN}

Penelitian ini dilakukan di salah satu Sekolah Menengah Atas (SMA) di Jakarta kelas XI MIPA tahun ajaran 2019/2020. Subjek penelitian ini adalah 104 siswa. Penelitian ini menggunakan instrumen tes dan non-tes. Penyusunan instrumen tes didasarkan dengan indikator kemampuan berpikir kritis matematis berjumlah 10 soal uraian dengan materi barisan 
dan deret. Sedangkan instrumen non-tes menggunakan instrumen skala Adversity Quotient (AQ). Instrumen AQ yang digunakan adalah instrumen yang diadaptasi dari Hidayat, et. al. (2018). Intrumen AQ terdiri dari 39 pernyataan, pilihan jawaban menggunakan skala Likert dengan 5 pilihan jawaban dalam bentuk "sangat setuju". "setuju", "netral", "tidak setuju" dan "sangat tidak setuju".

Instrumen tes dan non tes diukur menggunakan Model Rasch dibantu oleh software Winstep. Model Rasch menyajikan informasi diagnostik untuk tujuan mengevaluasi dan meningkatkan instrumen. Model Rasch menambahkan manfaat tambahan untuk penskalaan dan interpretasi (Willse, 2017). Angket AQ dianalisis menggunakan model Rasch dan data kemampuan berpikir kritis dihitung menggunakan nilai logit model Rasch kemudian dianalisis menggunakan SPSS versi 24.0. Ada pun indikator berpikir kritis matematis dirangkum dalam Tabel 1 di bawah ini (Karim \& Normaya, 2015).

Tabel 1. Indikator Berpikir Kritis

\begin{tabular}{|c|c|}
\hline Indikator & Keterangan Indikator \\
\hline Interpretasi & $\begin{array}{l}\text { Memahami masalah yang ditunjukkan dengan menulis diketahui maupun yang } \\
\text { ditanyakan soal dengan tepat. }\end{array}$ \\
\hline Analisis & $\begin{array}{l}\text { Mengidentifikasi hubungan-hubungan antara pernyataan-pernyataan, pertanyaan- } \\
\text { pertanyaan, dan konsep-konsep yang diberikan dalam soal yang ditunjukkan dengan } \\
\text { membuat model matematika dengan tepat dan memberi penjelasan dengan tepat. }\end{array}$ \\
\hline Evaluasi & $\begin{array}{l}\text { Menggunakan strategi yang tepat dalam menyelesaikan soal, lengkap dan benar } \\
\text { dalam melakukan perhitungan. }\end{array}$ \\
\hline Inferensi & Membuat kesimpulan dengan tepat. \\
\hline
\end{tabular}

Acuan dalam pengelompokkan kemampuan berpikir kritis diadaptasi dari Pertiwi (2018) yang dapat dilihat pada Tabel 2 berikut.

Tabel 2. Kategori hasil skor tes kemampuan berpikir kritis matematis

\begin{tabular}{cc}
\hline $\begin{array}{c}\text { Rentan skor tes kemampuan } \\
\text { berpikir kritis }\end{array}$ & Kategori \\
\hline $80 \leq$ skor $\leq 100$ & Sangat Baik \\
$66 \leq$ skor $\leq 79$ & Baik \\
$56 \leq$ skor $\leq 65$ & Sedang \\
$40 \leq$ skor $\leq 55$ & Kurang \\
$0 \leq$ skor $\leq 39$ & Sangat Kurang \\
\hline
\end{tabular}

\section{HASIL DAN PEMBAHASAN}

\section{Analisis Instrumen Adversity Quotient}

Tabel 3. Tampilan Summary Statistics AQ

\begin{tabular}{cccc}
\hline $\begin{array}{c}\text { Pearson } \\
\text { Measure }\end{array}$ & $\begin{array}{c}\text { Pearson } \\
\text { Reliability }\end{array}$ & Item Reliability & $\begin{array}{c}\text { Nilai Alpha } \\
\text { Cronbach }\end{array}$ \\
\hline$+0,56$ & 0,88 & 0,97 & 0,90 \\
\hline
\end{tabular}


Tabel 3 memberikan informasi tentang kualitas responden/peserta didik secara keseluruhan dalam menjawab angket yang diberikan. Dari tampilan hasil pengolahan di atas diperoleh person measure sebesar $+0,56$ logit lebih dari logit 0,0 menunjukkan bahwa responden/peserta didik memiliki kecenderungan untuk menyetujui item-item yang mengukur AQ (Sumintono \& Widhiarso, 2014). Hal ini dimaksudkan bahwa responden/peserta didik lebih banyak menjawab setuju pada pernyataan yang terdapat pada item. Nilai Pearson reliability dan item reliability berturut-turut sebesar 0,88 dan 0,97 . Hal ini menunjukkan bahwa konsistensi jawaban peserta didik dalam menjawab angket AQ bagus dan kualitas butir-butir pernyataan yang digunakan dalam instrumen AQ berkualitas istimewa (Sumintono \& Widhiarso, 2014). Dengan kata lain, responden menjawab keseluruhan item dengan sungguhsungguh (tidak asal-asalan) (Ardiyanti, 2017). Sedangkan keseluruhan angket AQ yang digunakan merupakan item-item yang berkualitas. Nilai alpha Cronbach sebesar 0,90 menunjukkan bahwa interaksi antara responden/peserta didik dengan item secara keseluruhan bagus sekali (Sumintono \& Widhiarso, 2014). Hal ini menunjukkan adanya kesesuaian antara instrumen dengan responden/peserta didik.

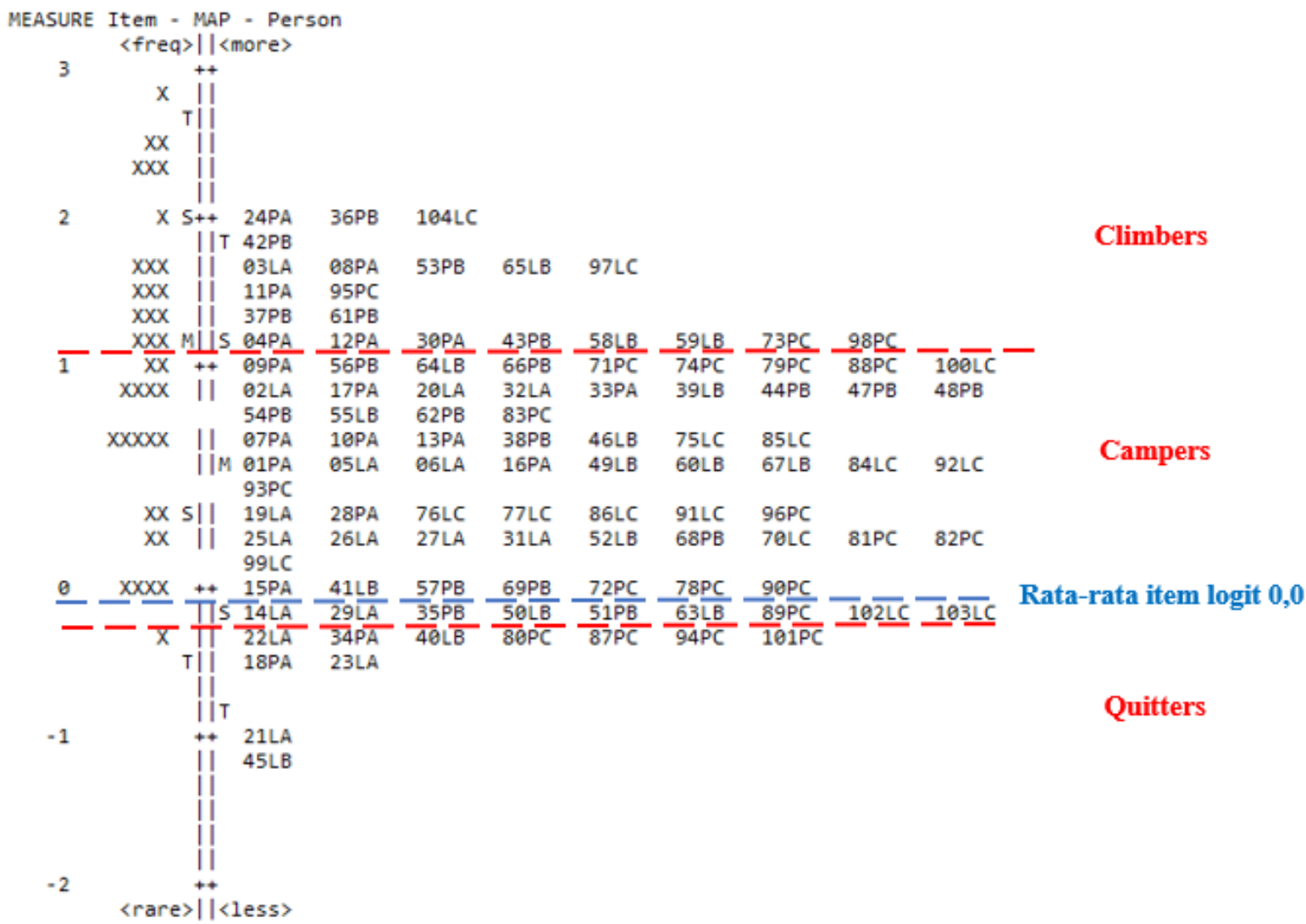

Gambar 1. Wright Maps dari Item Map Person 
Gambar 1 di atas, data yang dikumpulkan berasal dari 104 responden dianalisis menggunakan Winstep. Karakteristik responden menunjukkan kolom kiri adalah kolom item, dan kolom kanan adalah kolom responden. Nilai rata-rata yang lebih dari logit 0,0 menunjukkan kecenderungan responden yang lebih banyak menjawab setuju pada statement di berbagai item (Sumintono \& Widhiarso, 2014). Pembagian tipe AQ bersumber dari Mursidi \& Soeharto (2016) sehingga didapat tipe climber sebanyak 21 siswa dengan persentase sebesar 20,19\%, Tipe camper sebanyak 72 siswa dengan persentase sebesar 69,23\%, dan tipe quitter sebanyak 11 siswa dengan persentase sebanyak 10,58\%. Dari penjabaran tersebut dapat disimpulkan bahwa tipe AQ sebagian besar berada pada tipe camper dan yang terendah adalah tipe quitter.

\section{Analisis Instrumen Kemampuan Berpikir Kritis}

Tabel 4. Hasil tes kemampuan berpikir kritis matematis

\begin{tabular}{ccc}
\hline Intepretasi & Frekuensi & Kategori \\
\hline $80 \leq$ skor $\leq 100$ & 0 & Sangat Baik \\
$66 \leq$ skor $\leq 79$ & 6 & Baik \\
$56 \leq$ skor $\leq 65$ & 15 & Sedang \\
$40 \leq$ skor $\leq 55$ & 47 & Kurang \\
$0 \leq$ skor $\leq 39$ & 36 & Sangat Kurang \\
\hline
\end{tabular}

Berdasarkan Tabel 4 diperoleh hasil tes kemampuan berpikir kritis matematis peserta didik yang dihitung menggunakan pedoman penskoran sehingga didapat kategori sangat baik tidak ada satupun, kategori baik sebanyak 6 siswa (5,77\%), kategori sedang sebanyak 15 siswa $(14,42 \%)$, kategori kurang sebanyak 47 siswa $(45,19 \%)$, dan kategori sangat kurang sebanyak 36 siswa $(34,62 \%)$.

\section{Analisis Adversity Quotient dan Kemampuan Berpikir Kritis}

Berdasarkan analisis data penelitian terkait AQ dan kemampuan berpikir kritis matematis dihitung menggunakan data logit model Rasch kemudian dianalisis menggunakan SPSS, diperoleh data sampel yang berdistribusi normal menggunakan uji normalitas Shapiro-Wilk dengan nilai signifikansi sebesar 0,289 lebih besar dari 0,05 sehingga data berdistribusi normal. Selanjutnya dilakukan uji linearitas antara AQ dan kemampuan berpikir kritis matematis. Hasil rangkuman perhitungan disajikan pada Tabel 5 berikut ini. 
Tabel 5. Hasil uji linearitas AQ dan Kemampuan Berpikir Kritis

\begin{tabular}{|c|c|c|c|c|c|c|c|c|}
\hline & & & & $\begin{array}{c}\text { Sum of } \\
\text { Squares }\end{array}$ & df & $\begin{array}{c}\text { Mean } \\
\text { Square }\end{array}$ & $\mathbf{F}$ & Sig. \\
\hline Kemampuan & Between Groups & (Combined) & & 156,176 & 53 & 2,947 & 0,926 & 0,609 \\
\hline Berpikir & & Linearity & & 23,519 & 1 & 23,519 & 7,393 & 0,009 \\
\hline Kritis* & & Deviation & from & 132,657 & 52 & 2,551 & 0,802 & 0,784 \\
\hline Adversity & & Linearity & & & & & & \\
\hline \multicolumn{9}{|l|}{ Quotient } \\
\hline & Within Groups & & & 159,060 & 50 & 3,181 & & \\
\hline & Total & & & 315,235 & 103 & & & \\
\hline
\end{tabular}

Hasil uji linearitas antara AQ dan kemampuan berpikir kritis matematis pada tabel di atas menujukkan nilai Deviation from Linearity dengan nilai signifikansi sebesar 0,784 lebih besar dari 0,05. Hal ini menunjukkan bahwa ada hubungan linear secara signifikan antara Adversity Quotient dengan Kemampuan Berpikir Kritis. Langkah selanjutnya untuk mengetahui pengaruh AQ terhadap kemampuan berpikir kritis matematis dilakukan uji regresi dengan hasil yang disajikan pada Tabel 6 dan Tabel 7 berikut.

Tabel 6. Hasil uji regresi AQ terhadap kemampuan berpikir kritis

\begin{tabular}{llrcccc}
\hline Model & & $\begin{array}{r}\text { Sum of } \\
\text { Squares }\end{array}$ & df & $\begin{array}{c}\text { Mean } \\
\text { Squares }\end{array}$ & F & Sig. \\
\hline 1 & Regression & 23,519 & 1 & 23,519 & 8,224 & 0,005 \\
& Residual & 291,716 & 102 & 2,860 & & \\
& Total & 315,235 & 103 & & & \\
\hline
\end{tabular}

a. Dependent Variable : Kemampuan Berpikir Kritis

b. Predictors : (Constant), Adversity Quotient

Tabel 7. Pengaruh AQ terhadap kemampuan berpikir kritis

\begin{tabular}{lcccc}
\hline Model & R & R Square & $\begin{array}{c}\text { Adjusted R } \\
\text { Square }\end{array}$ & $\begin{array}{c}\text { Std. Error of the } \\
\text { Estimate }\end{array}$ \\
\hline 1 & 0,273 & 0,075 & 0,066 & 1,69114 \\
\hline a. & Predictors: (Constant), Adversity Quotient & \\
b. & Dependent Variable: Kemampuan Berpikir Kritis
\end{tabular}

Hasil uji regresi yang disajikan pada Tabel 6 dan Tabel 7, diperoleh kesimpulan bahwa terdapat pengaruh AQ terhadap kemampuan berpikir kritis matematis yang signifikan pada taraf signifikansi 5\% dengan nilai $R$ Square sebesar 0,075 . Hal ini menunjukkan bahwa pengaruh AQ terhadap kemampuan berpikir kritis matematis sebesar $75 \%$ sedangkan sisanya sebesar $25 \%$ dipengaruhi oleh faktor selain AQ. Pada penelitian sebelumnya yang dilakukan oleh Hidayat \& Sari (2019), pengaruh AQ terhadap kemampuan berpikir kritis sebesar $61 \%$. Langkah selanjutnya untuk mengetahui hubungan antara AQ dengan kemampuan berpikir kritis matematis dilakukan uji korelasi dengan hasil yang disajikan pada Tabel 8 berikut. 
Tabel 8. Hasil uji korelasi AQ dan kemampuan berpikir kritis

\begin{tabular}{llcc}
\hline & Adversity & $\begin{array}{c}\text { Kemampuan } \\
\text { Quotient }\end{array}$ & $\begin{array}{c}\text { Kerpikir Kritis } \\
\text { Berpion }\end{array}$ \\
\hline Adversity Quotient & Pearson Correlation & 1 & 0,273 \\
& Sig.(2-tailed) & 104 & 0,005 \\
& N & 0,273 & 104 \\
Kemampuan Berpikir & Pearson Correlation & 0,005 & 1 \\
Kritis & Sig.(2-tailed) & 104 & 104 \\
& N & & \\
\hline
\end{tabular}

Berdasarkan uji korelasi yang disajikan pada Tabel 8, diperoleh korelasi antara AQ dengan kemampuan berpikir kritis sebesar 0,005 kurang dari 0,05. Hal ini menunjukkan bahwa terdapat korelasi/hubungan yang signifikan antara AQ dan kemampuan berpikir kritis. Dari hasil tersebut berarti terdapat pengaruh AQ terhadap kemampuan berpikir kritis matematis serta memiliki hubungan yang signifikan antara AQ dan kemampuan berpikir kritis. Hal ini membuat peneliti membagi hasil kemampuan berpikir kritis matematis berdasarkan tipe-tipe AQ.

Berdasarkan hasil yang telah diuraikan di atas, terdapat tipe quitter di mana tipe tersebut merupakan kelompok orang yang kurang memiliki kemauan untuk menerima tantangan dalam hidupnya (Fauziyah et al., 2013). Tipe quitter dapat dikatakan termasuk dalam kategori AQ rendah (Hidayat \& Prabawanto, 2018; MZ et al., 2017). Hal ini sesuai dengan karakteristik siswa dengan AQ rendah (quitter) yang mudah menyerah ketika menemukan kesulitan dan berhenti tanpa dibarengi usaha sedikitpun (Hidayah et al., 2016). Gambar 2 berikut ini merupakan hasil pengerjaan siswa tipe quitter dalam menyelesaikan soal berpikir kritis yang termasuk ke dalam kategori berpikir kritis sangat kurang dan kategori berpikir kritis kurang.

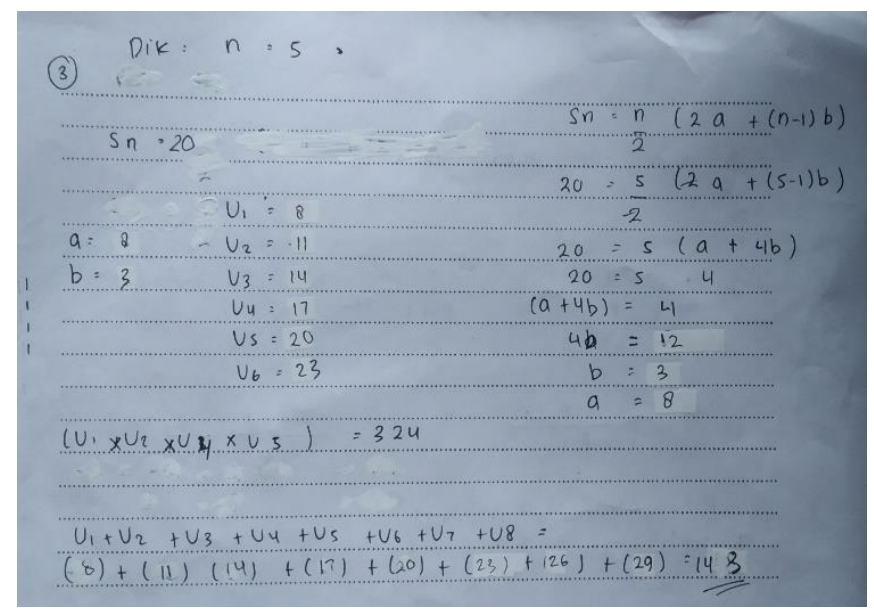

Gambar 2. Jawaban peserta didik dengan kategori berpikir kritis sangat kurang 
Berdasarkan Gambar 2 di atas peserta didik dalam mengerjakan tes kemampuan berpikir kritis tidak memenuhi keempat indikator berpikir kritis. Pada indikator interpretasi peserta didik ini tidak dapat memahami masalah yang ditunjukkan dengan tidak menulis diketahui maupun yang ditanyakan dengan tepat. Pada indikator analisis terlihat bahwa peserta didik tidak dapat memahami konsep dari materi barisan dan deret sehingga terlihat jelas pada indikator evaluasi peserta didik ini tidak menggunakan strategi yang tepat dalam menyelesaikan soal dengan lengkap dan benar dalam melakukan perhitungan sehingga hasil perhitungan yang didapat tidak benar. Sementara itu pada indikator inferensi, peserta didik tidak menuliskan kesimpulan yang didapat dalam menyelesaikan soal tersebut dan hasil perhitungan yang didapat tidak benar.

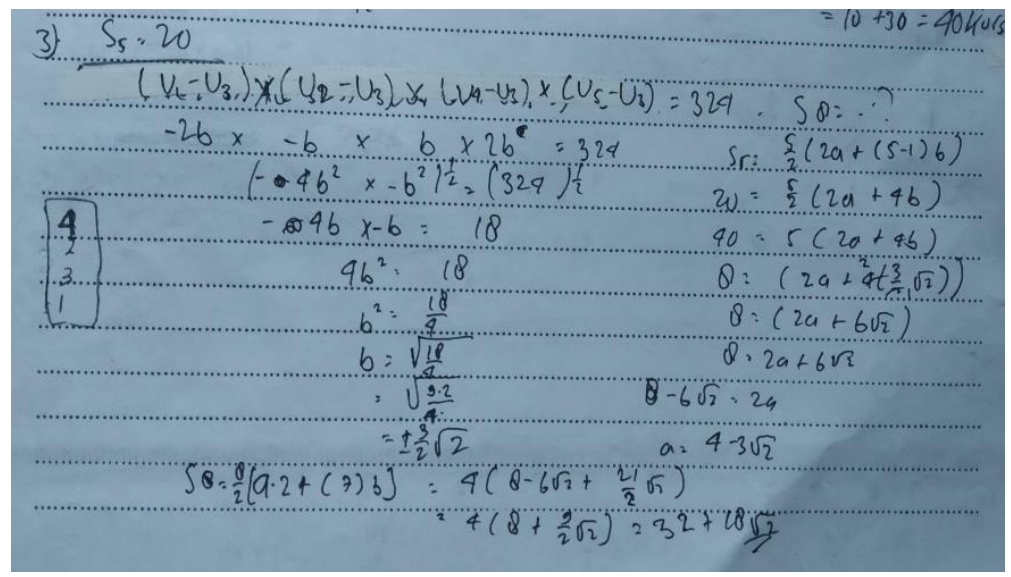

Gambar 3. Jawaban peserta didik dengan kategori berpikir kritis kurang

Berdasarkan Gambar 3 di atas terdapat indikator berpikir kritis yang tidak terpenuhi. Pada indikator interpretasi peserta didik ini dapat memahami masalah yang ditunjukkan dengan menulis diketahui maupun yang ditanyakan dengan tepat. Pada indikator analisis sebenarnya peserta didik ini dapat memahami konsep dari barisan dan deret namun pada indikator evaluasi dalam menyelesaikan soal terdapat kekeliruan dalam mengerjakan soal sehingga hasil perhitungan yang didapat tidak benar. Sementara itu pada indikator inferensi, peserta didik tidak menuliskan kesimpulan yang didapat dalam menyelesaikan soal tersebut dan hasil perhitungan yang didapat tidak benar.

Tipe AQ selanjutnya adalah tipe camper yang merupakan sekelompok orang di mana masih ada keinginan untuk menanggapi tantangan yang ada, tetapi tidak mencapai puncak kesuksesan dan mudah puas dengan apa yang sudah dicapai (Yani, et. al., 2016). Dapat dikatakan bahwa tipe camper termasuk dalam kategori AQ sedang (Hidayat \& Prabawanto, 2018; MZ et al., 2017). Hal tersebut sesuai dengan karakteristik siswa dengan AQ sedang yang 
cepat merasa puas dengan apa yang mereka kerjakan dan kerap mengabaikan kemungkinankemungkinan yang akan didapat (Hidayah et al., 2016). Berikut merupakan hasil pengerjaan siswa camper dalam menyelesaikan soal berpikir kritis yang termasuk kedalam kategori berpikir kritis sedang.

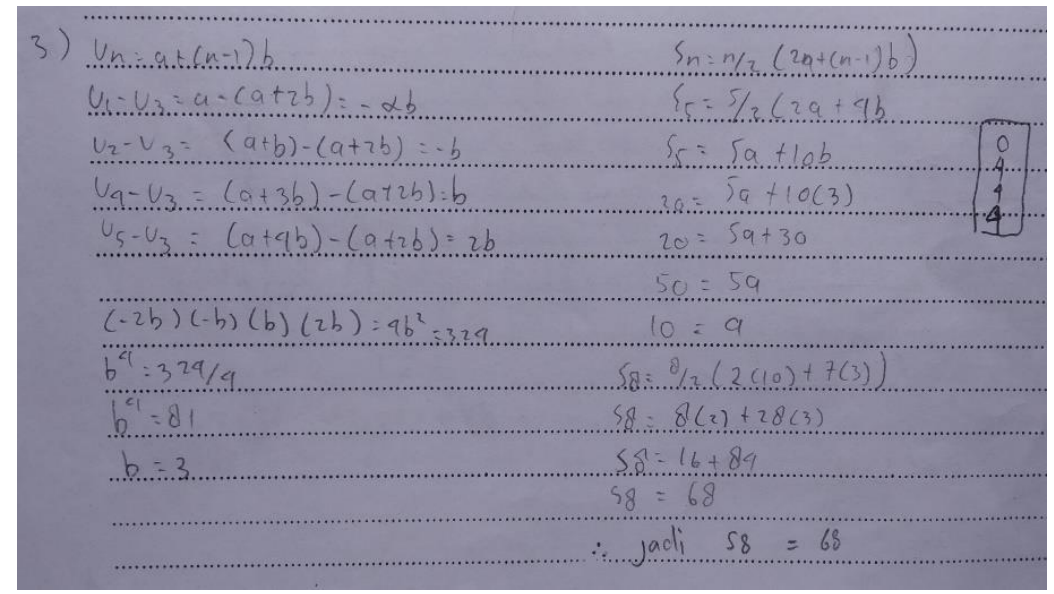

\section{Gambar 4. Jawaban peserta didik dengan kategori berpikir kritis sedang}

Berdasarkan Gambar 4 di atas terdapat indikator berpikir kritis yang belum terpenuhi. Pada indikator interpretasi, peserta didik ini tidak menulis diketahui maupun yang ditanyakan. Namun pada indikator analisis dan evaluasi, peserta didik ini dapat memahami konsep barisan dan deret terlihat pada pengerjaannya yang tepat serta menggunakan stategi yang tepat dalam menyelesaikan soal dengan lengkap dan benar dalam melakukan perhitungan sehingga hasil perhitungan yang didapat benar. Sementara itu pada indikator inferensi, peserta didik menuliskan kesimpulan yang didapat dalam menyelesaikan soal tersebut.

Tipe AQ yang terakhir yaitu tipe climber. Tipe ini merupakan kelompok orang yang memilih untuk terus bertahan untuk berjuang menghadapi berbagai macam hal yang akan terus menerjang, baik itu dapat berupa masalah, tantangan, hambatan, serta hal-hal lain yang terus didapat setiap harinya (Fauziyah et al., 2013). Tipe climber dapat dikatakan termasuk dalam kategori AQ tinggi (Hidayat \& Prabawanto, 2018; MZ et al., 2017). Hal tersebut sesuai dengan karakteristik siswa dengan AQ tinggi yang memiliki sifat ulet, gigih, dan memiliki keberanian untuk menggunakan solusi pemecahan masalah yang berbeda dengan siswa lainnya (Hidayah et al., 2016). Berikut merupakan hasil pengerjaan siswa climber dalam menyelesaikan soal berpikir kritis yang termasuk kedalam kategori berpikir kritis baik. 


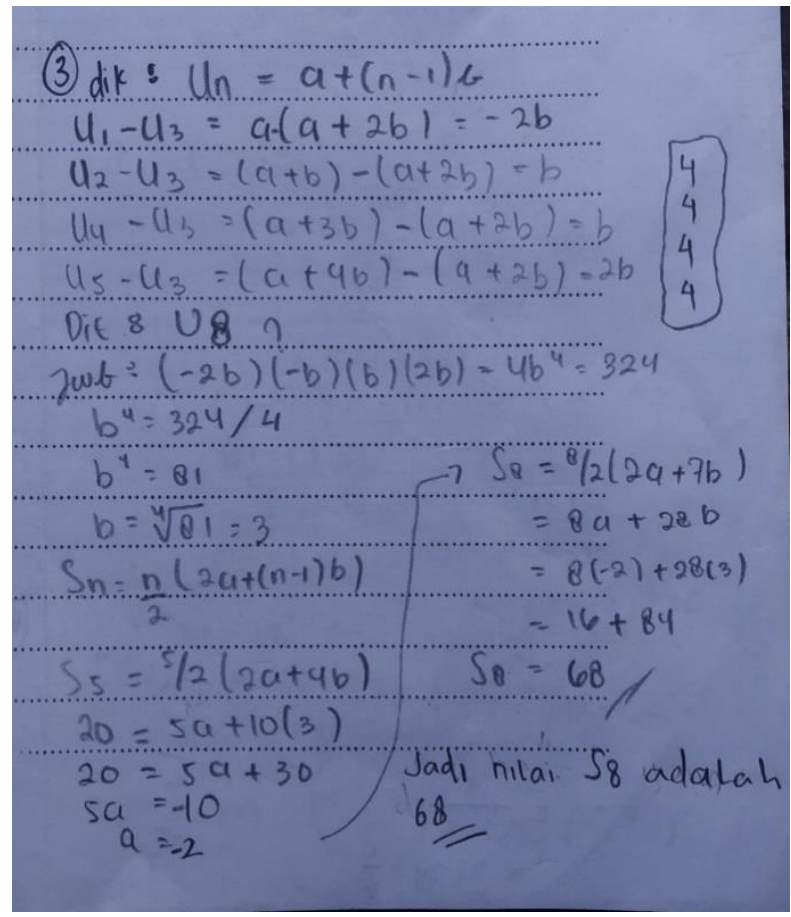

Gambar 5. Jawaban peserta didik dengan kategori berpikir kritis baik

Berdasarkan Gambar 5 di atas, semua indikator berpikir kritis terpenuhi. Pada indikator interpretasi peserta didik ini dapat memahami masalah yang ditunjukkan dengan menulis diketahui maupun yang ditanyakan dengan tepat. Pada indikator analisis dan evaluasi, peserta didik ini dapat memahami konsep barisan dan deret terlihat pada pengerjaannya yang tepat serta menggunakan stategi yang tepat dalam menyelesaikan soal dengan lengkap dan benar dalam melakukan perhitungan sehingga hasil perhitungan yang didapat benar. Sementara itu pada indikator inferensi, peserta didik menuliskan kesimpulan yang didapat dalam menyelesaikan soal tersebut.

\section{SIMPULAN DAN SARAN}

Berdasarkan hasil dan pembahasan analisis data, maka dikemukakan beberapa kesimpulan antara lain terdapat persebaran tipe-tipe AQ yaitu tipe climber 20,19\% siswa, tipe camper $69,23 \%$ siswa, dan tipe quitter 10,58\% siswa sehingga tipe AQ sebagian besar berada pada tipe camper. Terdapat pengaruh AQ terhadap kemampuan berpikir kritis matematis sebesar $75 \%$ sedangkan sisanya sebesar $25 \%$ dipengaruhi oleh faktor selain AQ. Dan adanya hubungan yang signifikan antara AQ dan kemampuan berpikir kritis sehingga terdapat penjabaran mengenai tipe AQ climber, camper, dan quitter.

\section{DAFTAR PUSTAKA}

Ab Kadir, M. A. (2017). What teacher knowledge matters in effectively developing critical 
thinkers in the 21 st century curriculum? Thinking Skills and Creativity, 23, 79-90. https://doi.org/10.1016/j.tsc.2016.10.011

Amanah, L. N. (2017). Pengaruh adversity quotient (aq) dan kemampuan berpikir kritis terhadap prestasi belajar matematika. Perspektif Ilmu Pendidikan, 28(1), 55. https://doi.org/10.21009/pip.281.7

Amin, D. M., \& Khabibah, M. (2019). Relational thinking in problem solving mathematics based on adversity quotient and visual learning style. International Journal of Trends in Mathematics Education Research, 2(4), 161-164. http://ijtmer.com

Anugerahwati, M. (2019). Integrating the 6cs of the 21st century education into the english lesson and the school literacy movement in secondary schools. KnE Social Sciences, 3(10), 165. https://doi.org/10.18502/kss.v3i10.3898

Ardiyanti, D. (2017). Aplikasi model rasch pada pengembangan skala efikasi diri dalam pengambilan keputusan karir siswa [application of the rasch model on the development of self-efficiency scale in student career decision making]. Jurnal Psikologi, 43(3), 248. https://doi.org/10.22146/jpsi.17801

As'ari, A. R., Mahmudi, A., \& Nuerlaelah, E. (2017). Our prospective mathematic teachers are not critical thinkers yet. Journal on Mathematics Education, 8(2), 145-156. https://doi.org/10.22342/jme.8.2.3961.145-156

Cretu, D. (2017). Fostering 21st century skills for future teachers. The European Proceedings of Social \& Behavioural Sciences, 672-681. https://doi.org/10.15405/epsbs.2017.05.02.82

Dhayanti, D., \& Johar, R. (2018). Improving students' critical and creative thinking through realistic mathematics education using geometer's sketchpad. Journal of Research and $\begin{array}{lll}\text { Advances } & \text { Mathematics } & \text { 3(1). }\end{array}$ http://journals.ums.ac.id/index.php/jramathedu

Facione, P. A. (2011). Critical thinking: What it is and why it counts. Insight assessment (Issue ISBN 13: 978-1-891557-07-1.).

Fauziyah, I. N. L., Usodo, B., \& Henny, E. ch. (2013). Proses berpikir kreatif siswa kelas X dalam memecahkan masalah geometri berdasarkan tahapan wallas ditinjau dari adversity quotient (aq) siswa. Jurnal Pendidikan Matematika Solusi, 1(1), 1-16.

Firdaus, I., \& Kailani, M. (2015). Developing critical thinking skills of students in mathematics learning. Journal of Education and Learning, 9(3).

Hidayah, S. R., Trapsilasiwi, D., \& Setiawani, S. (2016). Proses berpikir kritis siswa kelas vii 
f mts. Al-qodiri 1 Jember dalam pemecahan masalah matematika pokok bahasan segitiga dan segi empat ditinjau dari adversity quotient. Jurnal Edukasi, 3(3), 21. https://doi.org/10.19184/jukasi.v3i3.3517

Hidayat, W., Herdiman, I., Aripin, U., Yuliani, A., \& Maya, R. (2018). Adversity quotient (aq) dan penalaran kreatif matematis mahasiswa calon guru. Jurnal Elemen, 4(2), 230. https://doi.org/10.29408/jel.v4i2.701

Hidayat, W., \& Prabawanto, S. (2018). The mathematical argumentation ability and adversity quotient (aq) of pre-service mathematics teacher. Journal on Mathematics Education, 9(2), 239-248.

Hidayat, W., \& Sari, V. T. A. (2019). Kemampuan berpikir kritis matematis dan adversity quotient siswa smp. Jurnal Elemen, 5(2), 242. https://doi.org/10.29408/jel.v5i2.1454

Indriani, L. (2017). Teacher's role in 21 st century classroom. International Conference On Education, 1(1).

Karim, K., \& Normaya, N. (2015). Kemampuan berpikir kritis siswa dalam pembelajaran dalam pembelajaran matematika dengan menggunakan model jucama di sekolah menengah pertama. EDU-MAT: Jurnal Pendidikan Matematika, 3(1). https://doi.org/10.20527/edumat.v3i1.634

Kemendikbud. (2016). Peraturan Meneteri Pendidikan dan Kebudayaan No.20 tahun 2016 tentang Standar Isi Pendidikan Dasar dan Menengah. Jakarta: Kemendikbud.

Kusaeri, \& Aditomo, A. (2019). Pedagogical beliefs about critical thinking among indonesian mathematics pre-service teachers. International Journal of Instruction, 12(1). www.eiji.net

Lutfianto, M., \& Hartono, Y. (2013). Unfinished student answer in pisa mathematics contextual problem. Indonesian Mathematical Society Journal on Mathematics Education, 4(2), $188-193$.

Mahmuzah, R., \& Ikhsan, M. (2014). Peningkatan kemampuan berpikir kritis dan disposisi matematis siswa smp dengan menggunakan pendekatan problem posing. Jurnal Didaktik Matematika, 1(2), 43-53.

Mullis, I. V. S., Martin, M. O., Foy, P., \& Hooper, M. (2015). Timss 2015 international results in science saved. Distribution of Science Achievement. http://timss2015.org/timss2015/science/student-achievement/distribution-of-science-achievement/

Mursidi, A., \& Soeharto. (2016). An introduction: Evaluation of quality assurance for higher educational institutions using rasch model. Journal of Education, Teaching and 
Learning, 1(1), 1-6.

MZ, Z. A., Risnawati, R., Kurniati, A., \& Prahmana, R. C. I. (2017). Adversity quotient in mathematics learning (quantitative study on students boarding school in Pekanbaru). International Journal on Emerging Mathematics Education, 1(2), 169. https://doi.org/10.12928/ijeme.v1i2.5780

OECD. (2019). PISA 2018 Results: What Student Student Know and Can Do: Vol. I. https://doi.org/10.1787/5f07c754-en

Parvathy, U. (2014). Relationship between adversity quotient and academic problems among student teachers. IOSR Journal Of Humanities And Social Science (IOSR-JHSS), 19(11). Ver. VII. www.iosrjournals.org

Pertiwi, W. (2018). Analisis kemampuan berpikir kritis matematia peserta didik smk pada materi matriks. Pendidikan Tamnusai, 2(4), 793-801.

Rahman, A., Darwis, M., Asyari, S., \& Qadry, I. K. (2014). Teaching problem solving in mathematics learning: Reflection from pisa and timss result of the student of Indonesia. Proceeding of International Conference on Research.

Stoltz, P. G. (1997). Adversity Quotient: Turning Obstacles into Opportunities. Canada: John Wiley \& Sons, Inc.

Sumintono, B., \& Widhiarso, W. (2014). Aplikasi Model Rasch untuk Penelitian Ilmu-Ilmu Sosial (Revisi). Cimahi: Trim Komunikata Publishing House.

Tiruneh, D. T., De Cock, M., Weldeslassie, A. G., Elen, J., \& Janssen, R. (2017). Measuring critical thinking in physics: Development and validation of a critical thinking test in electricity and magnetism. International Journal of Science and Mathematics Education, 15(4), 663-682. https://doi.org/10.1007/s10763-016-9723-0

Widana, I. W. (2018). Higher order thinking skills assessment towards critical thinking on mathematics lesson. International Journal of Social Sciences and Humanities (IJSSH). https://doi.org/10.29332/ijssh.v2n1.74

Widyatiningtyas, R., Kusumah, Y. S., Sumarmo, U., \& Sabandar, J. (2015). The impact of problem-based learning approach to senior high school student's mathematics critical thinking ability. Indonesian Mathematical Society Journal on Mathematics Education, $6(2), 30-38$.

Willse, J. T. (2017). Polytomous rasch models in counseling assessment. Measurement and Evaluation in Counseling and Development, 50(4), 248-255. https://doi.org/10.1080/07481756.2017.1362656 
Yani, M., Ikhsan, M., \& Marwan, M. (2016). Proses berpikir siswa sekolah menengah pertama dalam memecahkan masalah matematika berdasarkan langkah-langkah Polya ditinjau dari adversity quotient. Jurnal Pendidikan Matematika, 10(1), 43-58.

Yanti, A. P., \& Syazali, M. (2016). Analisis proses berpikir siswa dalam memecahkan masalah matematika berdasarkan langkah-langkah Bransford dan Stein ditinjau dari adversity quotient. Jurnal Pendidikan Matematika, 7(1), 63-74. 